\title{
The Mental Health Review Tribunal and the restricted patient
}

\author{
Herschel Prins
}

\begin{abstract}
Some recent criticisms of Mental Health Reviow Tribunal proctices are reviewed against the background of concerns about public protection.
\end{abstract}

The purpose of Mental Health Review Tribunals (MHRTs) is to serve as a safeguard against wrongful admission or unwarrantedly long detention' (Wood, 1993a). More specifically, they 'give detained patients access to an effective appeal mechanism so as to ensure, as far as possible. legal protection of their liberty. It is in accord with strong current trends in all fields to give the individual rights of appeal or of complaint against faulty advice or treatment by professional groups (Wood, 1993b). In recent years, this need to protect the rights of the individual has had to be set against an increasing tendency to have regard for the protection of the public. This is reflected in recent criminal justice legislation (for example, the special sentencing provisions of the Criminal Justice Acts of 1991, 1993 and the Criminal Justice and Public Order Act of 1994). In mental health legislation, the need to consider protection of the public is reflected in the relevant sections of the Mental Health Act 1983, to make Hospital Orders with 'Restrictions' (Sects. 37/41) in order to protect the public from 'serious harm'. It is also reflected in the recently introduced Mental Health (Patients in the Community) Act 1995, with its provisions for 'after-care under supervision' which is intended to be applied to a small group of severely mentally ill detained patients considered to be potentially at risk of being a danger to themselves, to others, or at risk of serious exploitation. Finally, the Special Hospitals (now Health Authorities in their own right) exist under the provisions of Section 4 of the National Health Service Act of 1977 for the detention of patients demonstrating dangerous, violent or criminal propensities, who, if at large, would present an immediate and grave danger to the public. The State Hospital at Carstairs, Scotland makes similar provision.

\section{Balancing interests}

Expressed somewhat superficially, a Tribunal's functions are to balance delicate issues of personal freedoms against public protection (and, not infrequently, the protection of the patient from him or herself). Controversy is most likely to arise in those cases involving offenderpatients who have committed serious offences against persons or property and where judgements have to be made about the possibility of future 'mayhem'. It is worth emphasising that [this] work attracts a great deal of publicity and is closely monitored by groups representing patients. Soclety has additionally decreed that the law itself should be used to provide a form of overall supervision and the principal instrument of this is the system of Mental Health Review Tribunals' (Wood, 1995).

\section{Mental Health Review Tribunals under fire}

In view of the delicate and complex nature of these tasks, it is hardly surprising that, from time to time, MHRTs have been subjected to criticism and comment from a number of quarters. At one time, the Mental Health Act Commission (of which the author was a member for some time), and more recently. The Council on Tribunals have expressed concern about delays in Tribunal hearings and the need for members' training. Academics such as Peay (1989), have subjected MHRT powers and procedures to rigorous scrutiny, finding that in trying to serve the 'best interests' of patients the law may in some cases be 'bent' in order to serve these ends. It is also interesting to note that in the near 25-year existence of the 1959 Act, only a handful of cases went to Judicial Review. The 1983 Act has already provided over 40 such hearings, many of them concerned with the interpretation of the complex wording of the Tribunals' powers of discharge in respect of 'restricted' cases. Maybe one of the lessons to be derived from such reviews (and from other legislation, such as the Homicide Act, 1957), is that the law is not always an entirely satisfactory device for dealing with what might best be described as personal and social ills and that iatrogenic consequences may follow such attempts (See Prins, 1996a). 
We also live in an era of inquiries, public, private, or hybrid versions of both. It is of interest to observe how the emphasis has shifted from inquiries into institutional care (or lack of it) to investigations into fallures in community provision. In two recent inquiries, the activities of MHRTs came in for critical scrutiny and criticism (not all of it justifled). The first was the inquiry into the death of Georgina Robinson (an Occupational Therapist), at the hands of a patient, Andrew Robinson (no relation) at the Edith Morgan Centre, Torbay, Devon. In this case, the report of the Inquiry (Blom-Cooper et al, 1995) considered that the MHRT had been deficient in that it had failed to adjourn the hearing in the face of Robinson's failure to agree to being examined by the medical member. The second aspect that led to criticism by the Inquiry was the consistent 'downgrading' or 'devaluation' of Robinson's original (index) offence over the years in the eyes of those making judgements about him (Robinson had held a former girl-friend virtually hostage, in conditions which must have been highly traumatic for her). The Inquiry team considered that these two factors (among others) had led the MHRT to make a less than adequate assessment of the risk factors involved in granting Robinson an absolute discharge. It is worth noting that risk assessment now features prominently in the materials made available to and presented at training courses for recently appointed MHRT members, and features prominently in the recently published revised Members' Guide.

In the more recent case of Jason Mitchell (Blom-Cooper et al, 1996) further criticisms were made of MHRT practices. These concerned the need for MHRTs to have more detailed information about an offender-patient's index offence than they have avallable to them at present. They also suggested that the medical members of MHRTs dealing with restricted patients should be forensic psychiatrists. Even if this was possible (which seems unlikely, given the scarcity of forensic psychiatrists), it seems a somewhat dubious recommendation, one which seems to indicate, to some degree, a failure to understand sufficiently the functions of the medical member of the Tribunal panel. It is unfortunate that the Mitchell Inquiry Team seem to have been provided with less than adequate information concerning the current training afforded MHRT members. There are now two national residential two-day courses a year for recently appointed members. In addition, there are annual and ad hoc meetings of all members which invariably contain a training 'up-date' element. There is also a 'mentor scheme' through which newly appointed members are assigned to an experienced colleague in their discipline so that any queries or problems may be addressed on a more personal basis. As already indicated, the recently published Members' Guide (first published in 1988), has been considerably revised and extended (See Prins, $1996 b$ for further details).

\section{Lessons to be learned}

A basic lesson to be learned is the need for MHRTs to distinguish between 'risk', 'danger' and 'worry'. Risk can best be defined as the possibility of an event occurring and danger as denoting the amount of harm that may accompany that risk. Worry, as Grounds (1995) suggests, needs to be distinguished from both these terms. "I am worried about $X$ " is likely to be translated into " $X$ is a high risk" in written and spoken communications (Grounds, 1995). Central to the task of risk assessment is the business of assessing vulnerability. It is vital that MHRTs obtain not only a picture of the patient's own perceptions of his or her own health and attitudes, but that they make their judgements on the basis of the best information available medical, social and environmental. They need good, factual information which is up-to-date and relevant, so that a patient's version of events may be balanced against an accurate and full historical and contemporary record. In restricted cases, Tribunals have to rely heavily upon the information provided in the Home Office 'Statement'. The Home Office Mental Health Unit (formerly known as C3 Division) has recognised that, in some cases the flow and quality of information could be improved upon. To this end, they set up a small Working Group (of which the author was a member), to review their practices in relation to risk assessment and to examine what might be needed to further staff training in this respect. A small-scale survey of some 25 legal, medical and lay members experienced in dealing with restricted cases in the Trent and Northern and Yorkshire regions revealed a general desire for more detailed information from the Home Office, not only about the index offence, but about previous convictions (Prins, unpublished survey). The need for this more detalled information echoes the views of inquiry teams referred to above (Blom-Cooper et al, 1995; 1996).

The assessment and management of risk are often dominated by questions related to resources (both in terms of staff and 'bricks and mortar'). One sure way to 'set' a patient 'up to fail' is to return him or her to a situation similar to that which they were in immediately prior to the circumstances of civil admission or criminal admission. It is highly regrettable that deferred conditional discharges are frequently not implemented for many months (or even years) because suitable resources cannot be set in place. MHRTs will view very critically after-care plans that fail to 


\section{RISK ASSESSMENT}

take hold of obvious likely hazards. For example, with hindsight, one can see how unwise it was to allow the 'St Albans Poisoner' (the late Graham Young), to take up employment in a factory engaged in the manufacture of optical and allied equipment where poisonous substances were likely to be freely available. (In fact, he obtained the poison for his second series of crimes from a well known firm of London dispensing chemists.) Tribunal members, conscious of the fact that decisions to discharge are very frequently based upon social factors will wish for recommendations, based not only upon good factual analysis, but upon a realistic appraisal of the hazards a patient may have to face but, in addition, a certainty that the resources can be put in place to off-set these. They will wish to be satisfied that the professionals concerned have accepted Edmund Burke's dictum that 'Dangers by being despised grow great'.

\section{References}

BLOM-COOPER, L., HALLEY, H. \& MURPHY, E. (1995) The Falling Shadow: One Pattent's Mental Health Care: 1978 1993. London: Duckworth

-. Grounds, A., Guinan, P., et al (1996) The Case of Jason Mitchell: Report of the Independent Panel Of Inquiry. London: Duckworth.
Grounds, A. (1995) Risk Assessment and Management in Clinical Context. In Psychiatric Patient Violence: Risk and Response (ed. J. Crichton), pp. 43-59. London: Duckworth.

PEAY, J. (1989) Tribunals on Trial: Study of Decision Making Under The Mental Health Act, 1983. Oxford: Clarendon Press.

Prins, H. (1996a) Can the Law serve as the solution to social ills? The case of the Mental Health (Patients in the Community) Act, 1995. Medictine, Sclence and The Law. 38, 217-220.

- (1996b) Mental Health Review Tribunals: developing Good Practice. Tribunals, 3, 5-6.

WooD, Sir J. (1993a) Foreword to Annual Report: Mental Health Revlew Tribunals for England. London: Department of Health.

- (1993b) Reform of the Mental Health Act, 1983, an effective tribunal system. British Journal of Psychiatry. 162. 14-22.

- (1995) The challenge of indtvidual rights: Mental Health Review Tribunals. British Journal of Psychiatry. 168. 417-420.

Herschel Prins, Professor, Midlands Centre for Criminology and Criminal Justice, Loughborough University, Leicestershire LE11 3TU; and Lay member (Trent Region) and Chairman (19921996), National MHRT Training Group

Correspondence: 1 Home Close Road, Houghton-onHill, Leicestershire LE7 9GT 